\title{
Identification of Professional Behavior Attributes for Indonesian Medical Education
}

\author{
W. Kusumawati ${ }^{1}$, T.S. Prihatiningsih ${ }^{2}$, G.R. Rahayu ${ }^{3}$, S. Sastrowijoto ${ }^{4}$
}

\begin{abstract}
Professional Behavior (PB) is an observable behavior which reflects professional values, proven by behavior, speech and appearance that can increase patients' confidence of their doctor. PB is a component of professionalism which receives a lot of attention by the institution of medical education in Indonesia, with special reference to its pluralism, multicultural and multiethnic diversity.

This qualitative study was conducted to identify the PB attributes adjusted for the Indonesian context. The data collection included: 1) literature study; 2) in-depth interviews and 3) Focus Group Discussions (FGD). Participants interviewed were the chairman of the Center for Pancasila Study (PSP), chairman of center for religious cross cultural studies (CRCS), artists and Catholic, Hindu and Muslim religious leaders. Participant selection was purposeful, based on their links with the characteristic aspects of Indonesia. The FGD participants were the pertinent stakeholders and experts associated with the Medical and Health sciences education, health practitioners and physicians. Total of 26 FGD participants were grouped into 3 groups. Following analysis by the researchers, the qualitative data transcripts from FGD and interviews were randomly verified by other researchers. The qualitative data on the PB attributes from the literature and the interviews and FGDs were classified and categorized in three stages to avoid overlap, and collated to obtain the final PB attributes.
\end{abstract}

The results of this study indicated the presence of 34 of 133 identified PB attributes. The five PB attributes found in all sources were: 1) respect, 2) honesty; 3) integrity; 4) responsibility and 5) altruism. There were attributes only obtained from the Indonesian sources, namely a faith or belief in God Almighty. All PB could be realized best when based on the faith in the Lord as internal motivation. Amanah, Siddiq, Tablig, and Fathonah have long been important teachings for one of the biggest religions in Indonesia (Islam) in which honesty, integrity and responsibility are implied within it, three attributes of the five essential attributes gained from this research.

Keywords: professionalism replace by professional behavior, attributes, medical education

\section{Introduction}

Professional behavior (PB) is one of professionalism components that has nowadays received much attention from education experts and medical institutions. Unfortunately the PB has not actively been taught and assessed validly (Cohen 2001).

\footnotetext{
${ }^{1}$ Department of Medical Education and Pharmacology, Faculty of Medicine and Health Sciences Universitas Muhammadiyah Yogyakarta (FMHS UMY), Indonesia.

${ }^{2}$ Department of Medical Education, Faculty of Medicine Universitas Gadjah Mada, Indonesia.

${ }^{3}$ Department of Medical Education, Faculty of Medicine Universitas Gadjah Mada, Indonesia.

${ }^{4}$ Center of Bioethics and Humanity, Faculty of Medicine Universitas Gadjah Mada, Indonesia.

Corresponding author:

Wiwik Kusumawati, dr.,Mkes,

Department of Medical Education and Pharmacology, FMHS UMY, Indonesia

E mail:wiwik_fk_umy@yahoo.com.sg
}

According to Swick et al. (1999), the medical profession has suffered an erosion as a result of the behavior of physicians in their practice in providing health services that put more emphasis on other interests rather than on the benefit of patients. In addition, there is a tendency that the incidence of medical errors in hospitals is caused by increasing human factors.

According to the Indonesian Health Consumer Empowerment Foundation (YPKKI), malpractice in Indonesia has amounted to 60$65 \%$ and has been sourced from doctors (Kompas, 2009). However, studies proving its association with PB of doctors could not be found. Unprofessional behavior is a more common problem, frequently observed in doctors who receive disciplinary sanctions than issues with clinical skills. Residents have been identified to have a high risk associated 
with this in terms of interpersonal, professional behavior and or ethical problems (Cohen 2001).

Most complaints against doctors are related to incompetency. This is caused partly by lack of competence in professional behavior of the physician. Medical education so far has had more emphasis on cognitive and psychomotor learning. Affective competence, despite its importance, is not taught explicitly and assessed systematically (Korszun et al., 2005).

A physician's main task is to provide health services to the community. Good service for patients not only depends on cognitive and psychomotor competencies, but also on affective competence or professional behavior (Luijk, 2005). According to Wagner (2007) and Hays (2006), character, characteristic and behavioral development associated with professionalism should become an important area in medical education to complement the cognitive and psychomotor competencies in accordance with the expected goals. According Luijk (2005):"professional behavior refers to observable behavior that reflects professional standards and values. Professional behavior is evidenced by words, behavior, appearance and it is essential in establishing a basis of trust between patients and professionals".

Professionalism and professional behavior have become one important aspect of Indonesian physicians' competence standards, and in order to develop them, they should be formally taught and assessed in medical school curricula.

$\mathrm{PB}$ and its attributes have been incorporated into medical education in some countries. PB attributes or elements in medical curricular are similar in some regions or institutions. However, there are certain attributes of PB specific to each region or institution that needs to be identified. According to Luijk (2005), each institution needs to identify the PB attributes in accordance with existing needs and conditions. Indonesia with its pluralism, and a population of over 250 million is comprised of multiethnic and multicultural courses. There must be something different regarding the doctors' $\mathrm{PB}$ attributes that reflect these characteristics.

This study was conducted to identify the PB elements or attributes that fitted the Indonesian context as the first step of the medical professionalism development.

\section{Methods}

This research used a qualitative method. The qualitative approach was considered more appropriate to get an overview of the research subjects or respondents about the identification of PB attributes appropriate in the Indonesian context. The methods of data collection in this study consisted of: 1) literature survey, 2) in-depth interviews and 3) Focus Group Discussion (FGD).

The selection of research subjects in this study used purposeful sampling aiming to gain indepth data from information sources that were rich in information, so the sample size depended on the purpose and types of research (Patton, 1990). The chosen purposeful sampling was criterion sampling in which research subjects were selected based on specified criteria for the sake of research objectives. In-depth interviews were conducted by six resources persons and 26 stakeholders and experts associated with medical and health sciences education, members of professional organizations health practitioners and physicians participated in FGDs. Their relationship with the characteristics of Indonesia or a cultural trait was considered in selecting resource persons.

The six interview participants were as follows: 1) the chairman of the Center for Pancasila study (PSP), 2) the chairman of center for religious cross cultural studies (CRCS), 3) artist or puppeteer; 4) Muslim leaders; 5) Catholic religious figures and 6) Hindu religious leaders. The respondents or the FGD participants involved stakeholders and experts with these following criteria: 1) At least 10 years' experience in their field; 2) a minimum academic degree of S3 strata, 3) students having academic achievement above average and active in student organizations; and 4) concerned with education and health problems. FGD participants were grouped into 3. Group 1 consisted of practitioners and social activists, group 2 consisted of physicians, medical specialists and related health professions and group 3 consisted of medical experts and members of professional organizations. The selection of FGD respondents was done by directly contacting the respondents according to the criteria. Four divisions of medical specialists were chosen as representatives of their organization (an obstetrician and gynecologist, an internist, and a pediatrician and an ethics expert that was a surgeon). The profile of research subjects is shown in Table 1. 
Table 1. Profile of resource person

\begin{tabular}{|c|c|c|c|}
\hline $\begin{array}{c}\text { Respondent of } \\
\text { FGD } \\
\text { Group I }\end{array}$ & $\begin{array}{c}\text { Respondent of FGD } \\
\text { Group II }\end{array}$ & $\begin{array}{c}\text { Respondent of } \\
\text { FGD } \\
\text { Group III }\end{array}$ & $\begin{array}{l}\text { Resource person of } \\
\text { interview }\end{array}$ \\
\hline $\begin{array}{l}\text { Non-government } \\
\text { organization }\end{array}$ & Physician & $\begin{array}{l}\text { Expert of medical } \\
\text { education }\end{array}$ & $\begin{array}{l}\text { Chair of centered for } \\
\text { Pancasila study }\end{array}$ \\
\hline Journalist & Internist & $\begin{array}{l}\text { Expert of medical } \\
\text { ethics }\end{array}$ & $\begin{array}{l}\text { Chair of centered for } \\
\text { Religious Cross Cultural } \\
\text { Studies (CRCS) }\end{array}$ \\
\hline Psychologist & Pediatrician & $\begin{array}{l}\text { Expert of medical } \\
\text { communication }\end{array}$ & Humanist \\
\hline Sociologist & Obstetrician & $\begin{array}{l}\text { Ministry of health } \\
\text { (medical services) }\end{array}$ & Hindu religious leader \\
\hline Medical anthropologist & Surgeon & $\begin{array}{l}\text { Indonesian honorary } \\
\text { assembly } \\
\text { medical discipline } \\
\text { (MKDKI) }\end{array}$ & Catholic religious leader \\
\hline Religious leader & $\begin{array}{l}\text { Student of faculty of } \\
\text { medicine from } \\
\text { Universitas Gadjah Mada }\end{array}$ & $\begin{array}{l}\text { Indonesian Medical } \\
\text { Council (KKI) }\end{array}$ & Muslim leader \\
\hline \multirow[t]{3}{*}{ Lawyer } & $\begin{array}{l}\text { Student of faculty of } \\
\text { medicine from } \\
\text { Universitas Udayana } \\
\text { Community medicine }\end{array}$ & $\begin{array}{l}\text { Indonesian Medical } \\
\text { Association (IDI) } \\
\text { Association of } \\
\text { Indonesian Family } \\
\text { Physician (PDKI) }\end{array}$ & \\
\hline & Nurse & Health insurance & \\
\hline & Pharmacist & & \\
\hline
\end{tabular}

This research collected the data from previous literature and grouped them as national and international studies. The references from domestic sources included $\mathrm{Ki}$ Hajar Dewantara's textbook on education, Medical Competency Standard (IMC 2006), Medical Professional Education Standard (IMC 2006), Good Medical Practice (IMC, 2006), and other books and texts from other sources. The overseas references were from the National Board of Medical Education and American Association of Medical Education (2002) and other textbooks and journals searchable by keywords of professional behavior, professionalism, and teaching learning. The interviews and FGD transcripts were analyzed qualitatively. The transcripts of interviews and FGDs were randomly verified by other researchers. The qualitative analysis included: 1) describing; 2) unitizing; 3) categorization; 4) constant comparative method and 5) connecting categories (Dey cited by Savitri, 2007). All the findings from the references, interviews and FGDs were then grouped and categorized in three stages. The first stage was that the PB attributes were grouped under each source. The second stage was that the attributes were still grouped by their source, but PB overlapping attributes had begun to be analyzed and separated. The third stage was that to the PB attributes were collected into one and again analyzed in order to avoid overlap and PB final attributes were obtained.

\section{Results and Discussion}

The results of the PB attribute identification were grouped by source: references (overseas and domestic), FGDs and interviews. Through the three stages of categorization process, 34 PB attributes were obtained from original 133 PB attributes. The 34 PB attributes can be seen in Table 2. The results of this study presented the 5 PB attributes encountered from all sources (domestic and foreign literature, interviews and FGDs). The five PB attributes were namely: 1) respect, 2) honesty; 3 ) integrity; 4) responsibility and 5) altruism. The five identified PB attributes obtained from all sources and statements of the respondents or resources are shown in Table 2 
Table 2: Identification of 34 professional behavior (PB) attributes

\begin{tabular}{|c|c|c|c|}
\hline $\begin{array}{c}\text { PB } \\
\text { attributes } \\
\text { from } 4 \\
\text { resources }\end{array}$ & $\begin{array}{c}\text { PB attributes } \\
\text { from } 3 \text { resources }\end{array}$ & $\begin{array}{c}\text { PB attributes } \\
\text { from } 2 \text { resources }\end{array}$ & $\begin{array}{l}\text { PB attributes } \\
\text { from } 1 \text { resources }\end{array}$ \\
\hline Respect & Caring and compassion & Duty of care & $\begin{array}{c}\text { Teamwork (Gotong } \\
\text { royong) }\end{array}$ \\
\hline Honesty & Communication & Empathy & Appearance \\
\hline Integrity & Accountability & Humanism & Discipline \\
\hline Responsibility & Trust & Multi culture sensitivity & Polite, gentle \\
\hline \multirow[t]{6}{*}{ Altruism } & Leadership (manager) & Autonomy & $\begin{array}{l}\text { Friendly, smile and } \\
\text { compassionate }\end{array}$ \\
\hline & Morality & $\begin{array}{l}\text { Excellence/ } \\
\text { smart }\end{array}$ & Noble character \\
\hline & Ethics & Tolerance & Harmony \\
\hline & Religious ethics* & Commitment/ promise keeping & $\begin{array}{l}\text { Discussion } \\
\text { (musyawarah) }\end{array}$ \\
\hline & $\begin{array}{c}\text { Religiosity and } \\
\text { spirituality* }\end{array}$ & Confidentiality & Kinship \\
\hline & $\begin{array}{c}\text { Amanah, siddiq, tabligh, } \\
\text { fathonah }\end{array}$ & Social justice & \\
\hline
\end{tabular}

Notes : resources of attributes consists of 1) references from overseas; 2) references from Indonesia; 3) Focus Group Discussion and 4) interview; * only found from Indonesia

Respect

According to the American Board of Internal Medicine (ABIM, 2001), respect is reflected in the respect towards the patients and their families, other physicians and professional colleagues such as nurses, medical students, and residents. It is the essence of humanism, and humanism is both central to professionalism and fundamental to enhancing collegiality among physicians.

The definition of 'respect' by the other respondents was:

"The definition of takwamasi .... actually what is inside us is the same as what is inside other people. Then, we must respect others, meaning we respect ourselves. Hating others means hating ourselves...." (W.3)

"Respect and leadership, they must have them. In PBL, actually we learn to be a leader and mutually respect one another..... the facilitator must know that in PBL we must improve skills, respect, and so on" (F.III.3)

\section{Honesty and integrity}

Honesty and integrity implies being fair, being truthful, keeping one's word, meeting commitments, and being straightforward.
It also requires recognition of the possibility of conflict of interest and avoiding any situation in which the interest of the physician is placed above that of the patient or allowing personal gain to supersede the best interest of the patient. It constitutes an integral part of professionalism. The importance of professionalism in the patient/physician relationship cannot be overstated (ABIM, 2001).

Honesty and integrity can also defined as the consistent regard for the highest standards of behavior and refusal to violate one's personal and professional codes. According to one respondent, honesty and integrity was:

"PB has two (2) components, namely:

1. The professionalism of acting (the way of acting), an act that is visible by others,

2. The way of being (invisible), that is motives grown because of education, independent learning and environment, one of which is altruism.

There are three attributes in the way of being:

- Altruism (put others' interest (patient or community) above self-interest,

- Honesty (in revealing something based on a belief that what has been done is correct and not deceptive), 
- Promise keeping (following up something based on what has been promised), which is not frequently said.

Way of acting and way of being cannot sometimes be united. One can be seen correct, good, polite, and full of attention to the patient, but actually it is not like what is aforementioned in his heart." (F.II.3)

\section{Responsibility}

As members of a profession, physicians are expected to work collaboratively to maximize patient care, be respectful of one another, and participate in the processes of self-regulation, including remediation and discipline of members who have failed to meet professional standards. The profession should also define and organize the educational and standardsetting process for current and future members. Physicians have both individual and collective obligations to participate in these processes. These obligations include engaging in internal assessment and accepting external scrutiny of all aspects of their professional performance (Physician charter).

According to one respondent, responsibility was:

"A doctor is not only given medical or physical knowledge, but also other kinds of knowledge. We are talking about a morale value concerning responsibility; this must be broad in meaning, not merely in a narrow meaning, such as responsibility toward women, community as a whole" (F.I.1)

\section{Altruism}

Altruism constitutes the essence of professionalism and is based on the rule that the best interest of patients and not selfinterest is the professional obligation/ the rule (ABIM, 2001).

According to one respondent, altruism was:

"A good doctor does not take a side to the patients he handles. He has to explain something to his patient according to the local wisdom to avoid misunderstanding not explaining medical terms that are not understood by the patient" (W.3)

".........from the background of the personnel of Indonesian Doctor Association, I think a doctor will face patients not researchers. What is then needed are:

1. Trust. When are in a profession, we cannot get something before we have faith in it. However, doctors seem not to believe in PB.
2. Trust is something which can be accounted for.

3. Altruism, so that what can be believed and accounted for is an altruistic thing, not something being forced.

So the order is accountability, excellence, and so on as needed (F.II.2)

There were interesting findings obtained from the identification of $P B$ attributes found FGD and interviews and which were not found in the overseas references, including religious ethics or aspects of religiosity and spirituality (Amanah, Siddiq, Tabligh, Fathonah). Some statements from some respondents or informants relating to the importance of the character of the Prophet Muhammad can be seen below:

"..... which is important is the motivation to enter medical school, the motivation that is related to values. I emphasize that there must be an approach and the best one is a religious approach. It has faith in it.

1. A doctor can only try and only God heals. This can eradicate a doctor's pride

2. God sees, listens, and knows everything so that human can deny what is done in this world and they must responsible for what they have done in hereafter

3. The best motivation is worshipping; money can come and go and the rest is all about worshipping

4. Every human being is equal in God's eyes, so before a doctor, all people must be cared for, meaning putting others' interest above self-interests (F.I.4)

"If wanting to follow teachings brought by Prophet Muhammada, there will be four, namely Amanah, Siddiq, Siddiq means having authority and it can be trusted, meaning the authority in medicine is not like a game. As for its science, then becoming being in authority, meaning if a doctor is a medical specialist, he must do his job fully not a halfheartedly...... meaning it can be trusted from economic and social aspects, what I have said is as a whole...... tablig means wholesomeness, the communication in the delivery. Nothing is hidden. Fathonah is clear. A doctor must be Fathonah or smart in accordance with his knowledge or it is more than just being Fathonah. Smart in a technical meaning (W.6)

Respecting the doctor-patient relationship within the meaning of ABIM emphasizes more on patients, families, colleagues and other health professions. According to the FGDs and interviews, to respect was based on the equal position of human existence so that one 
respected others as he wanted to be respected (takwamasi). Moreover, respecting is not only to the rights, wishes and confidentiality of patients but also to doctors and nurses in the sense not to do things that are not in accordance with the code of conduct on certain conditions. Respect should also be given to life in the womb (genetic engineering for in vitro fertilization is not accepted).

Pancasila is the basis of the Indonesian ideology as well as a nation's Ideology that contains noble values in the five principles of Pancasila (Wuryadi, 2006). The importance of Pancasila for Indonesia overviewed from its history is as presented by the chairman of the PSP as follows:

“........values of Pancasila, namely divinity, humanity, unity, populist, democracy and social justice values, those values are universal .... formulated by experts who were very brilliant, very visionary to build Indonesia's future. Sukarno formulated the five universal values based on the highly historical course of Indonesia, the ethnic background and political interests, the nationalist forces ... it is necessary to overcome it with a good adhesive that is on the 5 principles"

Pancasila as an ideology of the nation has 45 point values that can be associated with the medical profession, especially principle numbers 1, 2, 4 and 5. Pancasila values associated with respect is the attitude of reverence or respect performed in religious life and to worship, human relations or social (not to impose the will, to respect the rights of others, to like to give aid) as well as working in teams (respect the decision taken).

Literature defines integrity, as being honest in all situations and interactions, when delivering information confidentiality, being consistent with the highest standards of behavior and refusal to conduct a violation of professional and individual ethics. The results of FGDs and interviews showed that honesty altruism and the promise keeping were considered as values by the participants Honesty is defined as "to reveal everything with the basic belief that what is done is true and not deceptive"; Honesty is one aspect of the 7 things to do and becomes a guide for practitioners. Honesty is the first feature of physician's professionalism and he should be honest when providing services in form of information, reports, research, financing and conflict of interest. Doctors need to show a high level of integrity to enhance their professionalism and personality as a role model in order to gain the trust from patients and society. According to the values of Pancasila, the integrity of a doctor in serving patients is indicated by patience, not arbitrarily treating patients, and recognizing human beings' equal rights without any discrimination in race, ancestry, religion, belief, gender, social status, and skin color, upholding human values as well as developing a noble deed, which reflects the attitude and atmosphere of kinship and mutual help (Wuryadi, 2006).

According to the Physician's Charter the professional responsibility of a physician is to be capable of working in collaboration, and with mutual respect for the team members to maximize patient care. According to the FGD and interview, participants felt that doctors had a responsibility to provide satisfactory health services for patients,. For example, after patients wait long, the doctor should check not in a hurry but greet or communicate with the patient and examine the patient with care, so that the patients are relieved after a long wait. Responsibility or liability has a broad meaning including the needs of female patients in examination and diagnosis and needs of society at large without offending them.

According to the values of Pancasila (Wuryadi, 2006), which is associated with physician professional behavior about responsibility is: Indonesian people believe in God and are pious to God's teachings in accordance the faith held adopted by civilized humanity, so that the Indonesian people have a responsibility as personal beings who relate to God in the account for all actions (the physician and patient relationship) to God Almighty.

According to ABIM, altruism prioritizes patients' interests above personal interests as a part of professional responsibility.

According to the FGDs and interviews, altruism was shown by an impartial attitude to the patient (more concerned with other people or patients than the self-interest) in the sense of understanding and considering the state of education, economy, culture and wishes of patients in diagnostic and therapeutic procedures and this attitude could be trusted and could be accounted for. According to the values of Pancasila, altruistic attitude is shown by not imposing the will to others, conduct of humanitarian activities, prioritizing everybody's interests above personal or a certain group's interest in a team work while also developing a noble deed, which reflects the attitude and atmosphere of kinship and mutual cooperation, developing a fair attitude toward others and liking to give help to others in order to be able to be independent. 
The results showed five important attributes of professional behavior (respect, honesty, integrity, responsibility and altruism) obtained from domestic and overseas references, FGDs and interviews. However, there were different attributes from religious ethics and religiosity, both of which could be realized as an attribute of faith or belief in one supreme God (Almighty). This is in accordance with the values contained in Pancasila principle number 1 concerning belief in one God, that the Indonesian nation is faithful and pious to God Almighty in accordance with their respective beliefs. In addition, there were attributes of Amanah, Siddiq, Tabligh, and Fathonah. Amanah found that means, in carrying out the medical profession, doctors should be trusted (by the patient) according to the prevailing ethic based on the knowledge and competencies they have. Amanah implies honesty, integrity, and responsibility. Siddiq means honesty. Tabligh means in communicating with patients both in terms of diagnosis and therapeutic as well as in conveying decision-making, the message must be clear and intact. Thus, tabligh also contains aspects of truth. Fathonah means intelligent, that doctors in their profession need to have a good scientific knowledge or competence (Wuryadi, 2006).

\section{Conclusion}

The results of this study indicate the presence of 34 PB attributes. Five PB attributes that are important and found in all sources are namely: 1) respect, 2) honesty; 3) integrity; 4) responsibility and 5) altruism. There is one attribute that characterizes Indonesia, that is the ethical religion, spirituality and religiosity that can be realized with the attribute of faith. All attributes can be realized with good PB in interaction of the physician-patient only if it is based on faith in God Almighty as an internal motivation. Amanah, Siddiq, Tabligh and Fathonah have long been an important teaching for one of the largest religions in Indonesia (Islam) and they imply honesty, integrity and responsibility, three attributes of the five essential attributes gained from this research.

\section{References}

American Board of Internal Medicine (ABIM) (2001) Project Professionalism, Philadelphia: American Board of Internal Medicine.

Ali, A.S. (2010) Nasionalisme, Kewargaan dan Pancasila dalam Nasionalisme dan Pembangunan Karakter Bangsa, Ed. Surono, Yogyakarta: PSP Pres.
Cohen, R. (2001) Assessing Professional Behaviour and Medical Error, Medical Teacher, 23, 2, pp. $145-151$.

Dewantara, K.H. (1977) Karja Ki Hadjar Dewantara Bagian Pertama: Pendidikan, Yogyakarta: Taman Siswa.

Hays, R. (2006) Teaching and Learning in Clinical Settings, Oxford: Radcliffe Publishing Ltd.

Kompas (2009) Wah, 60 Persen Kasus Malpraktek disebabkan Dokter.

Korszun, A., Winterburn, P.J., Sweetl, H., Jones, L.T. \& Houston H. (2005) Assessment of Professional Affective and Conduct in Medical Undergraduates, Medical Teacher, 27, 8, pp. 704 -708 .

Luijk, (2005) Teaching and penilaian of professional behavior, Maastricht: Universitaire Pers.

Patton, M.Q. (1990) Qualitative Evaluation and Research Methods, $2^{E d}$. London: Sage publications, Inc.

Savitri, T.P. (2007) Strategi Analisis Data Kualitatif untuk Penelitian Pendidikan Kedokteran dan Profesi Kesehatan, Jurnal Pendidikan Kedokteran dan Profesi Kesehatan Indonesia, 2, 1 , pp. $31-35$.

Swick, H.M., Szenas, P., Danoff, D. \& Whitcomb, M.E. (1999) Teaching Professionalism in Undergraduate Medical Education, Journal of the American Medical Association, 282, 9, pp. $830-832$.

Wagner, P., Hendrich, J., Moseley, G. \& Hudson, V.I. (2007) Defining Medical Professionalism : A Qualitative Study, Medical Education, 41, pp.288 $-294$.

Wuryadi (2006) Pancasila dalam Perspektif Pendidikan dan Kebudayaan Indonesia. Proceeding Simposium dan Sarasehan Pancasila sebagai Paradigma IImu Pengetahuan dan Pembangunan Bangsa. 